\title{
Evaluation of Herbicides Applied to Foliage of Four Tropical Woody Species
}

\author{
Clyde C. Dowler and F. H. Tschirley 1
}

\section{INTRODUCTION}

A number of plant species have been used to evaluate herbicides for the defoliation of tropical woody vegetation (Brun et al. (1), ${ }^{2}$ Dowler et al. (2), Tschirley (8), and Tschirley et al. (4)). Of these, guava (Psidium guajava L.), mango (Mangifera indica L.) and rose apple (Eugenia jambos L.) appeared resistant to some defoliants, as reported by Brun et al. (1). Miconia laevigata(L.) DC., however, was easily defoliated by several herbicides.

We evaluated 4-amino-3,5,6-trichloropicolinic acid (Picloram), 1,1'-dimethyl-4, $4^{\prime}$ bipyridium ion (Paraquat), (2,4-dichlorophenoxy)acetic acid $(2,4-\mathrm{D})$, and $(2,4,5$-trichlorophenoxy)acetic acid $(2,4,5-\mathrm{T})$, applied alone or in various combinations, as foliage sprays for the defoliation of the pantropical species guava, mango, rose apple, and camasey (Miconia prasina (Sw.) DC.).

\section{MATERIALS AND METHODS}

The test sites were located in the moist coastal area near Mayagüez, Puerto Rico, where a mean annual rainfall of 80 to 90 inches occurs. All treatments were applied at 10 g.p.a. with a telescoping-pole sprayer, as described by Dowler et al. (b).

Guava and camasey occurred in pure stands 10 to 15 feet tall. Five or six plants within each circular 40-foot diameter plot were tagged and data collected from the same sample set at each observation date. Three individual trees of mango and rose apple, ranging in height from 25 to 40 feet, received each treatment. Percent desiccation and/or defoliation was estimated 1, 3,6, and 12 months after treatment.

In addition to Paraquat, the following herbicide formulations were used: (a) $2 \mathrm{lb} . /$ gal. $\mathrm{K}$ salt of Picloram; (b) a mixture of $4 \mathrm{lb}$./gal. propylene glycol

1 Research Agronomist and Research Range Scientist, Crops Research Division, ARS, USDA, Federal Experiment Station, Mayagüez, P. R. Senior author now located at Georgia Coastal Plain Experiment Station, Tifton, Georgia; junior author at Plant Industry Station, Beltsville, Maryland.

This work reported is part of a program supported by the Advanced Research Projects Agency, Department of Defense. The authors wish to express their appreciation to Wilson Forestier, Wilfredo Santiago Mateo, René T. Hernández, and William Santiago Medina for their assistance. The herbicides were provided gratuicously by Cherron Chemical Company and Dow Chemical Company.

2 Italic numbers in parentheses refer to Literature Cited, p. 682. 
butyl ether esters of 2,4,5-T plus $1 \mathrm{lb}$./gal. isooctyl ester of Picloram, hereinafter referred to as 2,4,5-T:Picloram (4:1); (c) a mixture of $2 \mathrm{lb}$./ gal. n-butyl ester of 2,4-D plus $2 \mathrm{lb}$./gal. n-butyl ester of 2,4,5-T + $1 \mathrm{lb} . /$ gal. isooctyl ester of Picloram, hereinafter referred to as 2,4-D:2,4,5-T: Picloram (2:2:1); and (d) a mixture of $4 \mathrm{lb}$./gal. n-butyl ester of 2,4-D plus $4 \mathrm{lb}$./gal. n-butyl ester of 2,4,5-T, hereinafter referred to as 2,4-D: 2,4,5-T (1:1). Acetone was used as a carrier for 2,4,5-T:Picloram (4:1), 2,4-D:2,4,5-T:Picloram (2:2:1) and 2,4-D:2,4,5-T (1:1). Water was used as the diluent for Paraquat and Picloram. Acetone possessed no herbicidal properties at the volume applied.

\section{RESULTS}

GUAFA

On a lb./A. basis, Picloram was the most effective herbicide on guava (table 1). In general, $6 \mathrm{lb}$./A. of Picloram did not cause rapid defoliation. Except for the January 1966 treatment date, Picloram at $6 \mathrm{lb}$./A. caused as much defoliation 6 or 12 months after treatment as any other herbicide applied. The addition of Paraquat to Picloram increased the rate of desiccation or defoliation as compared to Picloram, but the percent defoliation 12 months after treatment was not increased except for the January 1966 treatment date. Paraquat at 9 or $12 \mathrm{lb}$./A. was not effective.

The fastest desiccation and defoliation of guava was caused by 2,4-D: 2,4,5-T (1:1) or 2,4,5-T:Picloram (4:1). Guava was defoliated more quickly and defoliation lasted longer when treated in August and October. The longer lasting defoliation also occurred on these treatment dates. Percentage defoliation was essentially the same for 2,4,5-T:Picloram (4:1) at $30 \mathrm{lb}$./A. and 2,4-D:2,4,5-T (1:1) at $24 \mathrm{lb}$./A. The herbicide 2,4,5$\mathrm{T}:$ Picloram (4:1) at $15 \mathrm{lb} . / \mathrm{A}$. did not defoliate as effectively as Picloram at $6 \mathrm{lb} . / \mathrm{A}$. or $2,4-\mathrm{D}: 2,4,5-\mathrm{T}(1: 1)$ at $24 \mathrm{lb} . / \mathrm{A}$.

Picloram at $4 \mathrm{lb} . / \mathrm{A}$. added to $2,4-\mathrm{D}: 2,4,5-\mathrm{T}(1: 1)$ at $8 \mathrm{lb} . / \mathrm{A}$. was less effective than Picloram at $6 \mathrm{lb}$./A. or 2,4-D:2,4,5-T (1:1) at $24 \mathrm{lb} . / \mathrm{A}$. when applied in May or August 1966. On the October 1966 treatment date, 2,4-D:2,4,5-T:Picloram (2:2:1) at $15 \mathrm{lb}$./A. defoliated essentially the same percent of guava leaves as Picloram at $6 \mathrm{lb}$./A. and 2,4-D:2,4,5-T (1:1) at $24 \mathrm{lb} . / \mathrm{A}$.

\section{MANGO}

Six and $12 \mathrm{lb} . / \mathrm{A}$. of Picloram were equally effective 12 months after application. There was no difference between November and May treatment dates (table 2). The addition of Paraquat to Picloram increased the rate of desiccation and defoliation as compared to Picloram at $6 \mathrm{lb} . / \mathrm{A}$., 
but long-term defoliation was not increased. Paraquat:Picloram (1:1) at $12 \mathrm{lb} . /$ A. applied in November 1965, caused less defoliation than did Picloram at $6 \mathrm{lb}$./A. 12 months after treatment.

TABLE 1.-Percent defoliation of guava (Psidium guajava L.) following January, May, August, and October 1966, foliage treatments of herbicides

\begin{tabular}{|c|c|c|c|c|c|}
\hline \multirow[t]{2}{*}{ Treatment date and herbicide } & \multirow{2}{*}{ 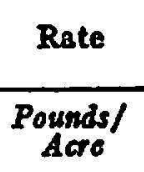 } & \multicolumn{4}{|c|}{$\begin{array}{c}\text { Desiccation and defoliation after } \\
\text { treatment }\end{array}$} \\
\hline & & I Montk & $\begin{array}{c}3 \\
\text { Months }\end{array}$ & Months & $\begin{array}{c}12 \\
\text { Months }\end{array}$ \\
\hline \multicolumn{6}{|l|}{ January, 1966} \\
\hline Picloram & 6 & $39 / 7$ & 56 & 67 & 47 \\
\hline Picloram & 12 & $85 / 7$ & 91 & 91 & 90 \\
\hline Paraquat:Picloram (1:1) & 12 & $78 / 72$ & 92 & 91 & 73 \\
\hline Paraquat & 9 & $16 / 16$ & 15 & 3 & 2 \\
\hline $2,4-\mathrm{D}: 2,4,5-\mathrm{T}(1: 1)$ & 18 & $97 / 50$ & 89 & 75 & 61 \\
\hline \multicolumn{6}{|l|}{ May, 1966} \\
\hline Picloram & 6 & $15 / 15$ & 53 & 53 & 92 \\
\hline Picloram & 12 & $17 / 10$ & 35 & 55 & 60 \\
\hline Paraquat:Picloram (1:1) & 12 & $27 / 25$ & 77 & 50 & 57 \\
\hline Paraquat & 12 & $32 / 21$ & 22 & 16 & 32 \\
\hline 2,4,5-T:Picloram (4:1) & 15 & $72 / 34$ & 80 & 54 & 58 \\
\hline 2,4,5-T:Picloram (4:1) & 30 & $98 / 36$ & 100 & 92 & 86 \\
\hline 2,4-D:2, 4,5-T (1:1) + Picloram & $8+4$ & $66 / 20$ & 95 & 73 & 74 \\
\hline $2,4-D: 2,4,5-T(1: 1)$ & 24 & $82 / 38$ & 92 & 70 & 81 \\
\hline \multicolumn{6}{|l|}{ August, 1966} \\
\hline Picloram & 6 & $81 / 61$ & 93 & 100 & 100 \\
\hline Picloram & 12 & $97 / 77$ & 100 & 100 & 100 \\
\hline Paraquat:Picloram (1:1) & 12 & $100 / 73$ & 100 & 103 & 100 \\
\hline 2,4,5-T:Picloram (4:1) & 15 & $82 / 57$ & 92 & 89 & 79 \\
\hline 2,4,5-T:Picloram (4:1) & 30 & $89 / 66$ & 98 & 96 & 96 \\
\hline 2,4-D:2,4,5-T (1:1) + Picloram & $8+4$ & $70 / 51$ & 77 & 79 & 74 \\
\hline $2,4-\mathrm{D}: 2,4,5-\mathrm{T}(1: 1)$ & 24 & $75 / 67$ & 79 & 79 & 95 \\
\hline \multicolumn{6}{|l|}{ October, 1966} \\
\hline Picloram & 6 & $93 / 54$ & 89 & 99 & 93 \\
\hline 2,4,5-T:Piclorsm (4:1) & 15 & $87 / 46$ & 95 & 91 & 82 \\
\hline 2,4-D:2,4,5-T:Picloram (2:2:1) & 7.5 & $95 / 56$ & 97 & 91 & 84 \\
\hline 2,4-D:2,4,5-T:Picloram (2:2:1) & 15 & $96 / 38$ & 99 & 97 & 92 \\
\hline 2,4-D:2,4,5-T (1:1) & 24 & $98 / 63$ & 96 & 99 & 98 \\
\hline
\end{tabular}

1 The figure to the left of the slash mark represents the percentage of leaves desiccated and defoliated; that to the right represents the percentage of defoliation. Single figures represent defoliation only.

Paraquat at $9 \mathrm{lb}$./A. applied in November desiccated mango leaves rapidly but regrowth also occurred rapidly. Results with 2,4-D:2,4,5-T (1:1) at $18 \mathrm{lb} . / \mathrm{A}$. were similar to those with Paraquat.

On the May 1966 treatment date, 2,4,5-T:Picloram (4:1) at $30 \mathrm{lb} . / \mathrm{A}$. 
and 2,4-D:2,4,5-T (1:1) at $24 \mathrm{lb} . / \mathrm{A}$. caused similar results on mango. Desiccation and defoliation of leaves occurred faster following 2,4-D: 2,4,5-T (1:1) treatment, but defoliation 12 months after application was essentially the same as with 2,4,5-T:Picloram (4:1). The 2,4-D:2,4,5-T (1:1) combination was more effective on mango applied in May than in November.

\section{ROSE APPLE}

The results were somewhat similar to those obtained on mango (table 3). Desiccation and defoliation of rose apple was greater than for mango.

TABLE 2.-Percent defoliation of mango (Mangifera indica $L$.) following foliage herbicide treatments in November 1965, and May 1966

\begin{tabular}{|c|c|c|c|c|c|}
\hline \multirow[t]{2}{*}{ Treatment date and berbicide } & \multirow{2}{*}{$\frac{\text { Rate }}{\begin{array}{c}\text { Pousnds/ } \\
\text { Acre }\end{array}}$} & \multicolumn{4}{|c|}{ Desiccation and defoliation 1 after treatment } \\
\hline & & $\stackrel{I}{I}$ onth & 3 Months & 6 Honths & $\begin{array}{c}12 \\
\text { Morths }\end{array}$ \\
\hline \multicolumn{6}{|l|}{ November, 1965} \\
\hline Picloram & 6 & $9 / 0$ & $33 / 18$ & $98 / 29$ & 100 \\
\hline Picloram & 12 & $15 / 3$ & $100 / 12$ & $100 / 62$ & 100 \\
\hline Paraquat:Picloram (1:1) & 12 & $75 / 25$ & $77 / 50$ & 58 & 78 \\
\hline Paraquat & 9 & $75 / 33$ & 23 & 9 & 32 \\
\hline $2,4-\mathrm{D}: 2,4,5-\mathrm{T}(1: 1)$ & 18 & $58 / 9$ & $70 / 12$ & $60 / 27$ & 33 \\
\hline \multicolumn{6}{|l|}{ May, 1966} \\
\hline Picloram & 6 & $2 / 0$ & $62 / 32$ & $100 / 85$ & 99 \\
\hline Picloram & 12 & $4 / 0$ & $100 / 67$ & $100 / 67$ & 97 \\
\hline Paraquat + Picloram (1:1) & 12 & $72 / 8$ & $100 / 60$ & $100 / 83$ & 100 \\
\hline 2,4,5-T:Picloram (4:1) & 30 & $27 / 0$ & $90 / 28$ & $73 / 30$ & 75 \\
\hline $2,4-\mathrm{D}: 2,4,5-\mathrm{T}(1: 1)$ & 24 & $52 / 2$ & $87 / 40$ & $88 / 57$ & 82 \\
\hline
\end{tabular}

1 The figure to the left of the alash mark represents the percentage of leaves desiccated and defoliated; that to the right represents the percentage of defoliation. Single figures represent defoliation only.

Twelve months after application to rose apple, all treatments containing Picloram (except 2,4,5-T:Picloram (4:1) at $15 \mathrm{lb} . / \mathrm{A}$. applied in May, 1966) caused 85 to 100 percent defoliation of the rose apple leaves.

Paraquat:Picloram (1:1) at $12 \mathrm{lb} . / \mathrm{A}$. desiccated rose apple leaves faster than any other treatment but long-term defoliation was no better than Picloram at $6 \mathrm{lb}$./A. The data in table 3 also indicates that a higher percentage defoliation occurred from treatments applied in May than from the same treatments applied in December.

\section{CAMASEY}

Foliage treatments of herbicides applied to camasey in August 1966, desiccated or defoliated 80 to 98 percent of the leaves within 1 month 
(table 4). All herbicides containing Picloram caused essentially complete defoliation within 3 months after application. These results remained the same for 12 months after application.

Picloram at $6 \mathrm{lb}$./A. applied in October 1966, did not desiccate or defoliate camasey leaves as fast as Picloram did when applied in August. However, 3 months or more after application there was no difference due to treatment date. Twelve months after application 2,4-D:2,4,5-T (1:1) did not defoliate as many camasey leaves when applied in October as when

Table 3. Percent defoliation of rose apple (Eugenia jambos $L$.) following foliage herbicide treatments in December 1965, and May 1966

\begin{tabular}{|c|c|c|c|c|c|}
\hline \multirow[t]{2}{*}{ Treatment date and herbicide } & \multirow{2}{*}{$\frac{\text { Rate }}{\text { Pounds/Acre }}$} & \multicolumn{4}{|c|}{ Dessication and defoliation after treatment } \\
\hline & & 1 Month & 3 Months & 6 Months & $\begin{array}{c}12 \\
\text { Months }\end{array}$ \\
\hline \multicolumn{6}{|l|}{ December, 1965} \\
\hline Picloram & 6 & $77 / 25$ & $77 / 55$ & $87 / 72$ & 90 \\
\hline Picloram & 12 & $62 / 15$ & $55 / 37$ & $57 / 52$ & 85 \\
\hline Paraquat:Picloram (1:1) & 12 & $88 / 25$ & $92 / 57$ & $92 / 82$ & 97 \\
\hline Paraquat & 9 & $33 / 22$ & $16 / 9$ & $18 / 12$ & 35 \\
\hline 2,4-D:2,4,5-T (1:1) & 18 & $82 / 15$ & $87 / 45$ & $75 / 50$ & 47 \\
\hline \multicolumn{6}{|l|}{ May, 1966} \\
\hline Picloram & 6 & $53 / 7$ & $77 / 40$ & $77 / 77$ & 98 \\
\hline Picloram & 12 & $65 / 15$ & $83 / 65$ & $91 / 91$ & 100 \\
\hline Paraquat + Picloram (1:1) & 12 & $93 / 22$ & $90 / 63$ & $92 / 75$ & 99 \\
\hline 2,4,5-T:Picloram (4:1) & 15 & $58 / 15$ & $70 / 30$ & $67 / 57$ & 70 \\
\hline 2,4,5-T:Picloram $(4: 1)$ & 30 & $75 / 22$ & $87 / 53$ & $87 / 80$ & 89 \\
\hline 2,4-D:2,4,5-T $(1: 1)+$ Picloram & $8+4$ & $70 / 17$ & $78 / 58$ & $77 / 7 \checkmark$ & 93 \\
\hline $2,4-D: 2,4,5-T$ & 24 & $67 / 15$ & $80 / 47$ & $60 / 60$ & 63 \\
\hline
\end{tabular}

1 The figure to the left of the slash mark represents the percentage of leaves desiccated and defoliated; that to the right represents the percentage of defoliation. Single figures represent defoliation only.

applied in August 1966. Also, 2,4-D:2,4,5-T:Picloram (2:2:1) at 7.5 lb./A. was almost as effective as 2,4-D:2,4,5-T (1:1) at $24 \mathrm{lb} . / \mathrm{A}$.

\section{DISCUSSION}

Twelve months after application Picloram applied at $6 \mathrm{lb} . / \mathrm{A}$. as a foliage treatment had induced a higher percentage of guava, mango, rose apple, and camasey leaf defoliation than any other herbicide or herbicide combination reported herein. Generally, Picloram at $6 \mathrm{lb}$./A. caused less desiccation and/or defoliation of leaves in the first month after treatment than any other herbicide treatment in this study. The addition of Paraquat at $6 \mathrm{lb}$./A. to Picloram increased the rate of phototoxic action as compared to Picloram alone but the long-term effects were not changed materially. There appeared to be an antagonistic effect of Paraquat on Picloram in 
some instances. Picloram applied at $6 \mathrm{lb} . / \mathrm{A}$. to guava in May 1966, caused 92 percent defoliation of the leaves 12 months after application, but Paraquat:Picloram (1:1) at $12 \mathrm{lb} . / \mathrm{A}$. caused only 57 percent defoliation of the leaves (table 1). This trend also occurred on the treatments applied to mango in November 1965 (table 2).

The addition of 2,4,5-T or 2,4-D:2,4,5-T to Picloram also increased the initial rate of desiccation or defoliation as compared to Picloram at $6 \mathrm{lb} . / \mathrm{A}$. alone. In several instances the defoliation 12 months after application was less when Picloram was combined with the phenoxyacetic acids.

Table 4. Percent defoliation of camasey (Miconia prasina (Sw.)DC.) following August and October 1966, foliage treatments of herbicides

\begin{tabular}{lcrrrr}
\hline \multicolumn{1}{c}{ Treatment date and herbicide } & Rate & \multicolumn{4}{c}{$\begin{array}{c}\text { Desiccation and defoliationt } \\
\text { after treatment }\end{array}$} \\
& Pounds/Acre & 1 Monsh & $\begin{array}{c}3 \\
\text { Months }\end{array}$ & $\begin{array}{c}\text { M } \\
\text { Months }\end{array}$ & $\begin{array}{c}\text { M2 } \\
\text { Montlss }\end{array}$ \\
August, 1966 & & & & & \\
Picloram & 6 & $95 / 93$ & 100 & 100 & 100 \\
Picloram & 12 & $98 / 88$ & 100 & 100 & 100 \\
Paraquat:Picloram (1:1) & 12 & $96 / 87$ & 99 & 100 & 100 \\
2,4,5-T:Picloram (4:1) & 15 & $97 / 93$ & 100 & 100 & 100 \\
2,4,5-T:Picloram (4:1) & 30 & $95 / 90$ & 97 & 99 & 100 \\
2,4-D:2,4,5-T (1:1) + Picloram & $8+4$ & $96 / 96$ & 99 & 100 & 100 \\
2,4-D:2,4,5-T (1:1) & 24 & $86 / 79$ & 90 & 98 & 95 \\
October, 1966 & & & & & \\
Picloram & 6 & $77 / 47$ & 98 & 100 & 100 \\
2,4-D:2.4,5-T:Picloram (2:2:1) & 7.5 & $68 / 28$ & 82 & 90 & 81 \\
2,4-D:2,4,5-T:Picloram (2:2:1) & 15 & $70 / 33$ & 91 & 97 & 92 \\
2,4-D:2,4,5-T (1:1) & 24 & $86 / 66$ & 91 & 97 & 85 \\
\hline
\end{tabular}

1 The figure to the left of the slash mark represents the percentage of leaves desiccated and defoliated; that to the right represents the percentage of defoliation. Single figures represent defoliation only.

The long-term defoliation that resulted from the phenoxyacetic acid-Picloram combination appeared to be influenced more by the amount of Picloram in the combinations than by the phenoxyacetic acids.

The herbicide 2,4-D:2,4,5-T (1:1) generally caused rapid desiccation and defoliation. The rate of desiccation was partially influenced by the herbicide formulation used.

Our data also suggests seasonal susceptibility of guava, mango, and rose apple to the herbicides we applied. Long-term defoliation was greater when the herbicides were applied during the rainy season (May-October) than when applied during the dry season (November-April). This trend was most evident for $2,4-\mathrm{D}: 2,4,5-\mathrm{T}(1: 1)$. On guava 2,4-D:2,4,5-T (1:1) caused 61 percent defoliation of the leaves when applied in January. Defoliation ranged from 81 to 98 percent when applied in May, August, or 
October. The same trend occurred in mango and rose apple. When Picloram at $6 \mathrm{lb}$./A. was applied to guava the above trend also was observed. These data, in general, support earlier conclusions reached by Tschirley et al. (4) in that season of herbicide application may influence long-term herbicidal activity on some tropical woody species.

\section{SUMMARY}

We applied the herbicides 4-amino-3,5,6-trichloropicolinic acid (Picloram), 1,1'-dimethyl-4,4'-bipyridinium ion (Paraquat), (2,4-dichlorophenoxy)acetic acid (2,4-D), and (2,4,5-trichlorophenoxy)acetic acid $(2,4,5-T)$, alone or in various combinations, as foliage sprays to guava (Psidium guajava L.), mango (Mangifera indica L.), rose apple (Eugenia jambos L.), and camasey (Miconia prasina (Sw.)DC.). A 1:1 mixture of Paraquat and Picloram at $12 \mathrm{lb} . / \mathrm{A}$. or 2,4-D:2,4,5-T (1:1) at $24 \mathrm{lb} . / \mathrm{A}$. generally desiccated and defoliated more leaves during the first month after treatment, but Picloram at $6 \mathrm{lb}$./A. caused more defoliation 12 months after treatment. Camasey was more susceptible to the herbicides tested than guava, mango, and rose apple.

\section{RESUMEN}

Aplicamos los yerbicidas Picloram (ácido 4-amino-3,5,6 tricloropicolínico); Paraquat (1,1'-dimetil-4,4'-ion bipiridino); 2,4-D (ácido 2,4 diclorofenoxacético); y 2,4,5-T (ácido 2,4,5-triclorofenoxacético, en forma de aspersión foliar, solos o en varias combinaciones, a la guayaba (Psidium guajava L.), el mango (Mangifera indica L.), la pomarrosa (Eugenia jambos L.) y el camasey (Miconia prasina (Sw.)DC.). Una mezcla de 1: 1 de Paraquat y Picloram, a razón de 12 libras por acre, 6 de 2,4-D:2,4,5-T (1:1), a raz6́n de 24 libras por acre, generalmente disecaron y defoliaron más hojas durante el primer mes después del tratamiento. Pero el Picloram, a razón de 6 libras por acre, causó más defoliación a los 12 meses después del tratamiento. El camasey fue más susceptible que la guayaba, el mango y la pomarrosa, a los yerbicidas que se probaron.

\section{LTTERATURE CITED}

1. Brun, W. A., Cruzado, H. J. and Muzik, T. J., The chemical defoliation and desiccation of tropical woody plants, Trop. Agr. 38: 69-81, 1961.

2. Dowler, C. C., Forestier, W. and Hernandez, R. T., (1968) The effect and persistence of herbicides applied to the soil in guava (Psidium guajava L.), Proc. SWC 81: 228-32, 1968.

3. Tschirley, F. H., Research Report-Response of tropical and subtropical woody plants to chemical treatments, CR-13-67., ARS, USDA, ARPA Order No. 424, U. S. Dept. of Defense. 197 p, 1968.

4. Tschirley, F. H., Hernóndez, R. T., and Dowler, C. C., Seasonal susceftibility of guava to selected herbicides, Weeds 15: 217-19, 1967.

b. Dowler, C. C., McCalmont, J. R. and Byrom, M. H., A method for spraying individual trees, We6d Sci. 17: 260-62, 1969. 